\title{
REVIEW
}

\section{Oesophageal reflux and asthma}

\author{
J.G. Ayres*, J.F. Miles**
}

Oesophageal reflux and asthma. J.G. Ayres, J.F. Miles. @eERS Journals Ltd 1996.

ABSTRACT: Asthma and gastro-oesophageal reflux commonly occur together but the association in any individual may or may not be causal. Aspiration of gastric acid into the trachea has been demonstrated in some patients with asthma with concomitant falls in lung function, while acid in the lower oesophagus can exacerbate asthma by a vagal reflex following stimulation of lower oesophageal receptors. Conversely, asthma can lead to worsening reflux both through the use of smooth muscle relaxing anti-asthma medication and by the mechanical effects of hyperinflation reducing lower oesophageal sphincter pressures. The effects on asthma following treatment of reflux has been anecdotally reported to be successful in some individuals, particularly those with severe reflux, but surgery should be reserved for individuals only after failure of medical treatment and should be aimed at improving reflux symptoms rather than improving asthma control.

Eur Respir J., 1996, 9, 1073-1078.
*Birmingham Heartlands Hospital, Bordesley Green East, Birmingham, UK. **North Manchester General Hospital, Delauneys Road, Crumpsall, Manchester, UK.

Correspondence: J.G. Ayres

Birmingham Heartlands Hospital

Bordesley Green East

Birmingham B9 5SS

UK

Keywords: Asthma

gastro-oesophageal reflux

microaspiration

oesophageal receptors

Received: January 261996

Accepted for publication January 281996
Asthma is a common chronic condition in the Western World, with an estimated prevalence of around 5\% in the adult population. Gastro-oesophageal reflux (GOR) is also common, with an equivalent prevalence in adults [1]. Clinically, the symptoms of GOR occur frequently in patients with asthma and reports of the prevalence of GOR in patients with asthma have ranged from $30-89 \%$ [2-6], suggesting that the possibility of a causal association should be considered.

Many early studies have attempted to address this issue by using assessments of GOR which have modest specificity and sensitivity, such as radiological contrast studies or endoscopy. The development of techniques for the ambulatory assessment of reflux of gastric contents by measurement of intraoesophageal $\mathrm{pH}$ over $24 \mathrm{~h} \mathrm{[7],}$ and by measurements of oesophageal motility and pressure [8], have advanced our knowledge of the relationship between asthma and GOR although there is, as yet, no complete agreement on the specific methodology to be used. Consequently, in this review, we will consider almost exclusively those studies which use state of the art technology for the assessment of GOR.

\section{Mechanistic considerations}

That reflux of gastric contents could exacerbate symptoms in patients with asthma (whether or not the contents may be acidic) makes scientific sense. The problem lies in deciding what the mechanism, or mechanisms, may be and whether different mechanisms might be important in individual patients.

Three main mechanisms have been proposed: 1) Frank aspiration of gastric contents into the lower respiratory tract [9]; 2) aspiration of gastric contents as far as the pharynx, causing symptoms by stimulation of irritant receptors [10]; and 3) reflux of gastric contents limited to the lower oesophagus causing symptoms either by increasing bronchial reactivity [11], or by bronchoconstriction secondary to a vagal reflex [12].

\section{Aspiration of gastric contents}

Microaspiration of gastric contents into the lung is difficult to assess. In the past, radionuclide studies applied the installation of a radionuclide directly into the stomach using a nasogastric tube and then assessed the amount of radioactivity present in the thorax after a defined period (usually following a period of sleep or recumbency). These studies had high specificity but very low sensitivity [13], and thus probably underestimated the extent of microaspiration.

An indirect method of detecting those patients in whom aspiration might occur employs the use of a $\mathrm{pH}$ electrode situated just below the upper oesophageal sphincter. This makes the assumption that patients who reflux to that anatomical level have an increased potential for aspiration, particularly during sleep when sphincter pressures are lower [14]. This idea was considered by SCHAN et al. [15], who studied three groups of patients (asthma with reflux disease, asthma alone, reflux disease alone) and a group of normal subjects. Using a dual $\mathrm{pH}$ probe with one probe $5 \mathrm{~cm}$ above the lower oesophageal sphincter and a second just below the upper sphincter, each individual was exposed to infusions of saline, $0.1 \mathrm{~N}$ hydrochloric acid and saline via an indwelling oesophageal tube whose tip lay in the mid-oesophagus. Exposures lasted 15-18 min and measures of forced expiratory volume in one second (FEV1), forced vital capacity (FVC), peak expiratory flow (PEF) and airways resistance were 
obtained at regular intervals. The data were acquired continuously using data-logging equipment. Interestingly, all four groups showed a fall in PEF during acid infusion. Subsequent saline infusion restored PEF in all groups except the asthmatics with reflux disease, whose PEF values remained lower. The same changes were seen in airway resistance, although the changes were of small degree (around $-5 \%$ ). The results of $24 \mathrm{~h} \mathrm{pH}$ monitoring confirmed a great degree of reflux in the two groups who complained of reflux symptoms, but neither the degree of proximal reflux nor the presence of a positive Bernstein test predicted the degree of change in lung function on acid infusion. The authors concluded that the symptoms of worsening asthma in a patient with GOR were not due to microaspiration and that, therefore, a vagally-mediated reflex was involved.

However, in a recent study JACK et al. [16] developed a method of direct measurement of intratracheal $\mathrm{pH}$, and this is the only study which has made a valid measurement of whether microaspiration occurs. The probe used was small (1 $\mathrm{mm}$ in diameter) and was introduced via a rigid bronchoscope under general anaesthesia. A probe was also inserted into the mid-oesophagus, the position of each probe being confirmed radiographically. Intratracheal and oesophageal $\mathrm{pH}$ data were acquired every $5 \mathrm{~s}$ onto a data-logger over a period of $24 \mathrm{~h}$. Four patients with asthma who complained of GOR symptoms were studied, as were three controls without either asthma or reflux symptoms who were undergoing bronchoscopy for an unrelated reason. Hourly recordings of PEF were made. Among the patients, 37 reflux episodes lasting more than 5 min occurred (57\% at night) and following five of these $(14 \%)$ there was an immediate fall in intratracheal $\mathrm{pH}$ (fig. 1) by a mean value of 3.0 units. Each of these five episodes was accompanied by a marked fall in PEF (mean fall $-84 \mathrm{~L} \cdot \mathrm{min}^{-1}$ ), 10 fold greater than the fall in PEF which occurred following an episode of GOR without tracheal aspiration.

The conclusion that can be drawn from these two studies $[15,16]$ is that in some patients microaspiration into the tracheobronchial tree can occur, assuming that the mere presence of an oesophageal electrode through the upper oesophageal sphincter does not in itself lead to loss of function of the sphincter. It is reasonable, however, to assume that this is not the case. Nevertheless, episodes of reflux into the oesophagus which do not reach the upper sphincter can also cause falls, albeit much smaller, in PEF, giving rise to the perhaps unsurprising conclusion that different mechanisms may apply in different individuals.

\section{Stimulation of upper airway irritant receptors}

Animal experiments have shown that large amounts of acid perfused over upper airway receptors can trigger the receptors and lead to bronchoconstriction [17]; however, the cumulative doses used in these studies were substantial. Bearing in mind the above-mentioned demonstration of intratracheal $\mathrm{pH}$ changes in patients with GOR, a mechanism involving irritation of upper airway receptors, whilst attractive, may prove of less importance than the reflex mechanisms following GOR limited to the lower oesophagus.

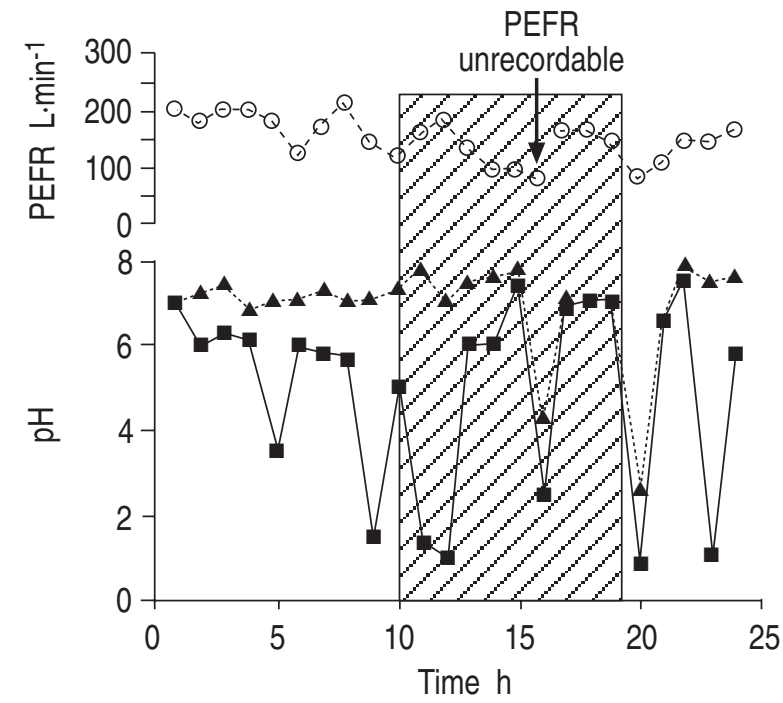

Fig. 1. - Contemporaneous recording of intratracheal ( $\mathbf{\Delta})$ and oesophageal (ם) $\mathrm{pH}$ and peak expiratory flow rate (PEF) in a patient with asthma and symptoms of gastro-oesophageal reflux (GOR). The shaded area refers to night-time, the horizontal axis being in hours from the beginning of the study (from [16] with permission).

\section{Stimulation of lower oesophageal receptors}

There is now good evidence that receptors in the lower oesophagus, when stimulated, can cause bronchoconstriction in patients with asthma via a vagal reflex. Nearly 20 yrs ago, studies of infusion of acid into the oesophagus were shown to cause increased airways resistance and reduction in small airways flow in patients with asthma who also had symptoms of GOR [12]. A later study [18] in 136 subjects, showed that acid infusion produced small decrements in FEV1, regardless of whether the subjects had symptoms or not. Pretreatment with intramuscular atropine in 18 subjects abolished this effect, with no change in mean FEV1 after acid infusion, suggesting that a vagal reflex was responsible. This was in contrast to the work by MANSFIELD and STEIN [12], who failed to show any changes in FEV1 following acid infusion in four groups of subjects with or without asthma and/or GOR. However, more recent work [15], mentioned above, whilst confirming no changes in spirometric variables, did show an effect on PEF, which persisted after saline perfusion of the oesophagus in patients with asthma and reflux, although the changes were modest. However, no attempts at vagal blockade were made in this study.

Definitive evidence of the presence of a role for vagal reflex mechanisms has come from a number of studies, which took as their starting point patients with chronic persistent cough for which no recognized cause could be found. IRwIN et al. [19] studied nine such patients using prolonged intraoesophageal $\mathrm{pH}$ monitoring, and correlated cough frequency to the number and duration of episodes of documented reflux. Cough frequency was shown to relate to the total number of refluxes, the longest episode of reflux, the number of prolonged refluxes $(\geq 5$ min) and the time that the lower oesophageal $\mathrm{pH}$ was $<4$. Three of the subjects had radiographic evidence of reflux on contrast radiology and a further three subsequently admitted to symptoms suggestive of GOR. The great majority of the documented episodes of reflux were 
Table 1. - Chronic persistent cough and relationship to reflux episodes and duration

\begin{tabular}{lcc}
\hline & $\begin{array}{c}\text { Cases } \\
\mathrm{n}=13\end{array}$ & $\begin{array}{c}\text { Controls } \\
\mathrm{n}=9\end{array}$ \\
\hline $\begin{array}{l}\text { Episodes of reflux } \\
\mathrm{n} \cdot 24 \mathrm{~h}^{-1}\end{array}$ & $115.8(31.7)$ & $4.7(1.4)^{* *}$ \\
$\begin{array}{l}\text { Duration of reflux } \\
\text { episodes min } \\
\text { Duration of lower } \\
\text { oesophageal pH }<4 \\
\text { min.24 h }\end{array}$ & $15.5(5.8)$ & $1.7(0.5)^{*}$ \\
\hline
\end{tabular}

Values are presented as mean, and SEM in parenthesis. *,**: $\mathrm{p}<0.007,0.0001$. (From [19]).

limited to the lower (distal) oesophagus and treatment with $\mathrm{H}_{2}$ receptor blockade was generally effective in reducing cough, suggesting acid per se was the trigger for the symptom rather that the mere presence of gastric contents within the lower oesophagus. These workers did not, however, study a control group of patients.

A later study from Australia [20] investigated 13 patients with chronic cough and nine controls without cough or symptoms of GOR. Of the 13 patients with cough, three admitted to mild symptoms of GOR but only after the onset of cough. All parameters of oesophageal reflux were considerably greater in cases than controls (table 1). This study also confirmed the findings of IRwIN et al. [19] that the episodes of cough often occurred in close relationship to episodes of reflux. Cough occurred either simultaneously or within $5 \mathrm{~min}$ of an episode of reflux in $48 \%$ of reflux episodes, whereas reflux occurred simultaneously with over three quarters of episodes of cough. The authors suggested that not only might a local, probably vagal, neural reflux be responsible for cough in these patients but that cough amplifies reflux, either by increasing transdiaphragmatic pressure or by inducing transient relaxation of the lower oesophageal sphincter.

The same group extended their work with an elegant series of acid perfusion and blockade studies [21]. Again, using a control group as comparators, and recording cough by microphone, subjects were studied during hydrochloric acid perfusion of the lower oesophagus. Patients showed greater numbers of coughing episodes with greater amplitude (measured in decibels) than controls with hydrochloric acid perfusion. Blockade studies were performed in six patients using inhaled ipratropium bromide, oesophageally-instilled ipratropium and oesophageallyinstilled lignocaine prior to acid infusion on three separate occasions. Both oesophageal lignocaine and inhaled ipratropium almost completely blocked the cough response to acid, whereas oesophageal ipratropium had no such effect (table 2). The logical conclusion from these studies is that cough induced by GOR is mediated by a reflex from receptors in the lower oesophagus, the efferent limb being vagal, with the afferent limb being as yet undetermined. However, it would appear that the presence of macroscopic oesophagitis is not necessary for this response to occur.

The presence of such receptors in the lower oesophagus has been identified in animals [22], and oesophageal perfusion with hydrochloric acid in asthmatics can cause reflux bronchoconstriction $[12,23]$, which is blocked by
Table 2. - Blockade of cough induced by oesophageal acid infusion

\begin{tabular}{|c|c|c|c|c|c|}
\hline \multirow[t]{2}{*}{ Blocking agent } & \multirow[t]{2}{*}{$\mathrm{n}$} & \multicolumn{2}{|c|}{$\begin{array}{c}\text { Cough frequency } \\
\mathrm{n} \cdot 15 \mathrm{~min}^{-1}\end{array}$} & \multicolumn{2}{|c|}{$\begin{array}{c}\text { Cough latency } \\
\mathrm{s}\end{array}$} \\
\hline & & Pre & Post & Pre & Post \\
\hline $\begin{array}{l}\text { Oesophageal } \\
\text { lignocaine }\end{array}$ & 7 & 41 & $9^{\dagger}$ & 9 & $231^{\dagger}$ \\
\hline $\begin{array}{l}\text { Inhaled } \\
\text { ipratropium bromide }\end{array}$ & 6 & 51 & $1^{\dagger}$ & 78.5 & $628^{\dagger}$ \\
\hline $\begin{array}{l}\text { Oesophageal } \\
\text { ipratropium bromide }\end{array}$ & 6 & 51 & 43 & 78.5 & 100 \\
\hline
\end{tabular}

Pre: preblockade; Post: postblockade. $\uparrow: \mathrm{p}<0.02$ compared to preblockade value. (From [21]).

intravenous atropine [23]. It would be reasonable to invoke this mechanism as a potential cause of worsening asthma, even in patients with no overt symptoms of GOR.

What is not entirely clear is whether gastric acid or some other factor(s) present in the gastric reflux fluid is/are responsible for initiating stimulation of oesophageal receptors. The acid perfusion studies would tend to support the predominant role of acid but a repeat series of studies, perhaps utilizing pepsin infusion into the lower oesophagus, which has been implicated in the oesophageal damage associated with reflux oesophagitis [24], would be of interest. Anecdotal reports that $\mathrm{H}_{2}$ blockade improves symptoms of GOR but often has no impact on asthma symptoms might point to factors other than acid being involved. However, studies from BRESLIN and coworkers [25] and IRWIN and et al. [19] would tend to suggest that a combination of anti-acid and more general anti-reflux measures can improve symptoms in their patients with cough.

In children, $24 \mathrm{~h}$ oesophageal $\mathrm{pH}$ monitoring is not so easy to perform but it has been shown that an acid drink in children with significant asthma enhances nonspecific bronchial reactivity [26], suggesting that similar responses can occur in children as in adults.

\section{Mechanical changes due to asthma as a cause of GOR}

Hyperinflation is a common, although not universal, occurrence in patients with asthma. The degree of hyperinflation may vary and during worsening asthma may become quite marked, with increases in the total lung capacity (TLC), residual volume (RV) and functional residual capacity (FRC). This results in a reduction in intrathoracic pressure, thus lowering the lower oesophageal sphincter (LOS) pressure and permitting GOR to occur more easily, an observation made over 30 yrs ago [27]. However, we know of no studies which have specifically related indices of GOR measured from intraoesophageal $\mathrm{pH}$ and pressure monitoring to the degree of hyperinflation per se. Another potential mechanism whereby hyperinflation might facilitate GOR is by allowing the lower oesophageal sphincter to be drawn up into the thorax, thus removing its ability to act as a functional valve. 
A study from out department of 17 patients suffering from severe asthma has contributed information to this area [28]. All patients had severe asthma, taking on average 2,230 $\mu \mathrm{g} \cdot \mathrm{day}^{-1}$ of inhaled steroids. Two were using regular nebulized bronchodilators and $10(58 \%)$ were being treated with subcutaneous infusions of terbutaline to control wide variations in their PEF. All patients complained of persistent, and often very severe, symptoms of GOR and overt reflux was confirmed in 16 by means of $24 \mathrm{~h}$ intraoesophageal $\mathrm{pH}$ monitoring. Mean percentage reflux time $(\mathrm{pH}<4)$ was $8.7 \%$ of $24 \mathrm{~h}$ and thus significantly more than the $2.5 \%$ found in a small control group, matched for age, sex and dose of inhaled steroids. Ten of the $17(58 \%)$ had herniation of the lower oesophageal sphincter into the thorax. Interestingly, in this very severe group of patients with asthma, mean TLC was $91 \%$ predicted and mean FRC $85 \%$ predicted. This would suggest that hyperinflation was not a major contributor to the generation of GOR in these patients and that other factors might play a part, chief amongst which is the amount and type of treatment for asthma used by these severely asthmatic patients.

\section{Asthma treatment as a cause of GOR}

Beta-agonists relax smooth muscle and, thus, have the potential to reduce LOS tone and to promote GOR. Intravenous administration of the nonselective $\beta$-agonist, isoprenaline, caused a significant reduction in LOS pressure [29], at doses which were, however, high compared to the usual inhaled dose. A study of inhaled salbutamol $(200 \mu \mathrm{g})$ in normal, healthy volunteers [30] showed no change in oesophageal motility nor did it elicit GOR. In a later study of oral salbutamol (4 mg), normal healthy volunteers and patients with asthma were similarly negative [31], although the asthmatic subjects had a significantly higher LOS pressure at rest.

Heartburn is a well-recognized problem in patients taking oral theophylline preparations, an effect which is not related to blood theophylline levels [32] and appears to be idiosyncratic. However, specific studies of the effect of oral theophylline preparations on GOR have shown some effects on LOS pressure [33, 34]. In a study of normal subjects, theophylline administrations producing blood levels in the therapeutic range, caused a mean reduction in LOS pressure of $25 \%$, with all 15 subjects showing reductions by at least $14 \%$, whereas in a smaller group exposed to placebo, there was, if anything, a slight rise in LOS pressure $(+5.6 \%)$ [33]. This suggests that pressure changes can be induced by theophylline preparations and can thus predispose to GOR. There is no published work on the possible effects of nebulized bronchodilators on GOR and no dose-response studies.

\section{Treatment of GOR in the presence of asthma}

Treatment of symptomatic GOR in the patient with asthma should follow exactly the same guidelines as for GOR alone, and this is not the appropriate place to discuss the relative merits of each treatment. However, such treatment, even with $\mathrm{H}_{2}$ blockers which effectively reduce gastric $\mathrm{pH}$ and nocturnal acid secretion, has shown only a small improvement in asthma symptoms, with a $15 \%$ improvement in nocturnal scores and a $10 \%$ reduction in bronchodilator use [35]. The dose of $\mathrm{H}_{2}$ blocker was modest in each case, which may explain the relative lack of effect.

The proton pump inhibitor, omeprazole, has been reported [36] to produce remarkable improvements in asthma control in a single case study, whilst a later case study in a patient with severe asthma and GOR [37] showed control of GOR symptoms but no improvement in asthma. This latter finding is supported by our study of GOR in severe brittle asthma [28], in which omeprazole was very effective in most cases in controlling GOR symptoms but had no significant beneficial effect on asthma control. Drugs such as $\mathrm{H}_{2}$ blockers and proton pump inhibitors do, of course, work by stopping or markedly reducing acid production but will have little effect on reducing the volume of refluxate or the bile content, both of which may in themselves stimulate lower oesophageal receptors and maintain asthma symptoms.

Surgery can, undoubtedly, play a role in the management of GOR in the asthmatic patient, although care must be taken in selecting patients for such an approach. It is our belief that before being considered for surgery, patients must have failed on conventional therapy with either $\mathrm{H}_{2}$ blockers or proton pump inhibitors, along with antacids and the usual nondrug measures. The published work in this area tends to indicate that surgery can help some but not all patients.

A series of 100 patients with GOR documented by $24 \mathrm{~h}$ $\mathrm{pH}$ monitoring [38] detected nine patients who were believed to demonstrate frank aspiration of gastric refluxate by association of symptoms with episodes of GOR. Five were operated on (the surgical procedure(s) were not specified) and lower oesophageal sphincter pressure increased but there was no clear assessment of any benefits with respect to respiratory symptoms postoperatively.

In a large $(n=89)$ series of children undergoing gastrooesophageal fundoplication, 42 had presented with chronic pulmonary disease, the predominant disease being chronic/recurrent pneumonitis [39]. Seventeen had asthma and 14 were followed-up closely postoperatively. Although no clear data were presented in the paper, improvements in asthma were seen in the majority of these children.

In an attempt to clarify the role of surgery, a remarkable study attempted to compare the medical and surgical approaches to GOR with respect to asthma control [40]. Ninety four patients with GOR and adult onset, nonallergic asthma were randomly allotted to one of three treatment arms, namely, oral cimetidine, placebo orally, or anti-reflux surgery. GOR had been confirmed either radiographically $(36 \%)$ or by intraoesophageal $\mathrm{pH}$ monitoring following a gastric hydrochloric acid load (64\%). Four refused to enter the study and, of the 30 randomized to receive surgery, a further four refused. The type of surgery used was a modified posterior gastropexy. Both cimetidine and surgery were found to be more effective than placebo in controlling symptoms of wheezing and reducing use of medication, which was maintained at 6 months. In the first 2 months following both cimetidine and surgery, there were minor changes in maximal mid-expiratory flow (MMEF) and also, although to a lesser extent, in FEV1. After this period, however, both FEV1 and MMEF after surgery tended to move towards 
the values seen in the placebo group, whilst the improvement with cimetidine was maintained.

Earlier surgical studies had not allowed accurate assessment of success or otherwise because of lack of lung function tests or indications of whether reflux was effectively controlled by surgery [41-43]. Two studies in children appeared to suggest improvement in the symptoms when considering the group as a whole $[44,45]$.

While the study by LARRAINE et al. [40] carefully excluded atopic patients and active cigarette smokers, they deliberately selected patients whose GOR symptoms were mild. It is, perhaps, curious that such patients were considered for surgery when, in many cases, symptoms were trivial or nonexistent. It would appear, therefore, that surgery should be reserved for patients who have failed adequate medical treatment, whose symptoms are intractable and whose pulmonary state allows surgical intervention.

\section{Summary}

In conclusion, it can be stated that much is still to be learnt about the interrelationship between asthma and gastro-oesophageal reflux. Both conditions are common and, hence, the association may be merely apparent rather than real. However, plausible mechanisms whereby uncontrolled asthma or asthma drugs may predispose to, or facilitate, gastro-oesophageal reflux have been described. Also, the presence of acid in the lower and upper oesophageal tract has been linked to changes in airway calibre through stimulation of oesophageal receptors and subsequent vagal reflex bronchoconstriction. At present, the treatment of gastro-oesophageal reflux, either by drugs or surgery has been studied in either too small a number, or by studies incorporating too insensitive a measure of asthma morbidity, to allow the sanctioning of routine evaluation of gastro-oesophageal reflux in all patients with asthma. Nevertheless, some patients with severe symptoms of reflux show some improvement in their asthma with medical treatment and, in selected cases, surgical treatment of their gastro-oesophageal reflux.

\section{References}

1. Wienbeck M, Barnet J. Epidemiology of reflux disease and reflux oesophagitis. Scand J Gastroenterol 1989; 24 (Suppl. 156): 7-13.

2. Goldman J, Bennett JR. Gastro-oesophageal reflux and respiratory disorders in adults. Lancet 1988; ii: 493-395.

3. Harding SM, Richter JE. Gastroesophageal reflux disease and asthma. Semin Gastrointestinal Dis 1992; 3: 139-150.

4. Mays EE. Intrinsic asthma in adults in association with gastroesophageal reflux. JAMA 1976; 236: 2626-2628.

5. Kjellen G, Brundin A, Tibbling L, Wranne B. Oesophageal function in asthmatics. Eur J Respir Dis 1981; 62: 87-94.

6. Sontag SJ, Schnell TG, Miller TQ, et al. Prevalence of esophagitis in asthmatics. Gut 1992; 33: 872-876.

7. De Meester TR, Wang C, Wesley JA, et al. Technique, indications and clinical use of 24 hour oesophageal monitoring. J Thorac Cardiovasc Surg 1980; 79: 656-670.

8. Allen SM, Van Raemdonck DE, Adams IP, Matthews
HR. Primary immotile oesophagus in young patients. Eur J Cardiothorac Surg 1993; 7: 337-341.

9. Goldman JM, Bennett JR. Gastro-oesophagael reflux and asthma: a common association, but of what clinical importance? Gut 1990; 31: 1-3.

10. Boyle JT, Tuchman DN, Altschuler SM, et al. Mechanisms for the association of gastroesophageal reflux and bronchospasm. Am Rev Respir Dis 1985; 131 (Suppl.): S16-S20.

11. Ekström T, Tibbling L. Esophageal acid perfusion, airway function, and symptoms in asthmatic patients with marked bronchial hyperreactivity. Chest 1989; 96: 995-998.

12. Mansfield LE, Stein MR. Gastro-oesophageal reflux and asthma: a possible reflex mechanism. Ann Allergy 1978; 41: 224-226.

13. Ghaed N, Stein MR. Assessment of a technique for scintigraphic monitoring of pulmonary aspiration of gastric contents in asthmatics with gastro-oesophageal reflux. Ann Allergy 1979; 42: 306-308.

14. Kahrilas PJ, Dodds WJ, Dent J, Haeberle B, Hogan WJ, Arndorfer RC. Effects of sleep, spontaneous gastroesophageal reflux, and a meal on upper esophageal sphincter pressure in normal human volunteers. Gastroenterology 1987; 92: 466-478.

15. Schan CA, Harding SM, Haile JM, Bradley LA, Richter JE. Gastro-oesophageal reflux-induced bronchoconstriction: an intraoesophageal acid infusion study using state of the art technology. Chest 1994; 106: 731-737.

16. Jack CIA, Calverley PMA, Donnelly RJ, Tran J, Russell G, Hind CRK. Simultaneous tracheal and oesophageal $\mathrm{pH}$ measurements in asthmatic patients with gastrooesophageal reflux. Thorax 1995; 50: 201-204.

17. Wynne JW, Ramphal R, Hood CI. Tracheal mucosal damage after aspiration: a scanning electron microscope study. Am Rev Respir Dis 1981; 124: 728-732.

18. Wright RA, Millar SA, Corsello BF. Acid-induced esophago-bronchial-cardiac reflexes in humans. Gastroenterology 1990; 99: 71-73.

19. Irwin RS, Zawacki JK, Curley FJ, French CL, Hoffman PJ. Chronic cough as the sole presenting manifestation of gastroesophageal reflux. Am Rev Respir Dis 1989; 140: 1294-1300.

20. Ing AJ, Ngu MC, Breslin ABX. Chronic persistent cough and gastro-oesophageal reflux. Thorax 1991; 46: 479-483.

21. Ing AJ, Ngu MC, Breslin ABX. Pathogenesis of chronic persistent cough associated with gastroesophageal reflux. Am J Respir Crit Care Med 1994; 149: 160-167.

22. Harding R, Titchen DA. Chemosensitive vagal endings in the oesophagus of the cat. J Physiol (Lond) 1975; 247: 52-53P.

23. Andersen Ll, Schmidt A, Bundagaard A. Pulmonary function and acid application in the oesophagus. Chest 1986; 90: 358-363.

24. Gotley DC, Morgan AP, Ball D, Owen RW, Cooper MJ. Composition of gastro-oesophageal refluxate. Gut 1991; 32: 1093-1099.

25. Ing AJ, Ngu MC, Breslin ABX. A randomised, doubleblind, placebo-controlled, cross-over study of ranitidine in patients with chronic persistent cough associated with gastroesophageal reflux. Am Rev Respir Dis 1992; 145(4): A11.

26. Wilson NM, Charrette L, Thomson AH, Silverman M. Gastroesophageal reflux and childhood asthma. Thorax 1985; 40: 592-597.

27. Clemencon GE, Osterman P. Hiatal hernia in bronchial asthma: the importance of concomitant emphysema. Gastroenterol 1961; 95: 110-115.

28. Miles JF, Noble K, Mathews HR, Cayton RM, Ayres 
JG. Gastroesophageal reflux in patients with brittle asthma. Thorax 1993; 48: 1055.

29. Zfass AM, Prince R, Allen FN, Farrar JT. Inhibitory beta-adrenergic receptors in the human distal esophagus. Am J Dig Dis 1970; 15: 303-310.

30. Schindlbeck NE, Heinrich C, Huber RM, Muller-Lissner SA. Effects of salbuterol (salbutamol) on esophageal motility and gastroesophageal reflux in healthy volunteers. JAMA 1988; 260: 3156-3158.

31. Michond MC, Leduc T, Proulx F, et al. Effect of salbutamol on gastroesophageal reflux in healthy volunteers and patients with asthma. J Allergy Clin Immunol 1991; 87: 762-767.

32. Arbab OA, Wiggins J, Ayres JG, Stableforth DE. The use of parenteral aminophylline in patients taking slow release theophylline preparations: an observation of clinical practice. Br J Dis Chest 1985; 79: 161-171.

33. Stein MR, Towner TG, Weber RW, et al. The effect of theophylline on the lower oesophageal sphincter pressure. Ann Allergy 1980; 45: 238-241.

34. Berquist WE, Rachelefsky GS, Kadden M, et al. Effect of theophylline on gastro-oesophageal reflux in normal adults. J Allergy Clin Immunol 1981; 67: 407-411.

35. Ekstrom T, Lindgren BR, Tibbling L. Effects of ranitidine treatment on patients with asthma and a history of gastro-oesophageal reflux: a double-blind cross-over study. Thorax 1989; 44: 19-23.

36. Prichard PJ, Yeomans ND, Mihaly GW, Jones DB, Buckle PJ. Omeprazole: a study of its inhibition of gastric $\mathrm{pH}$ and oral pharmacokinetics after morning and evening dosage. Gastroenterol 1985; 88: 64-69.
37. Depla AC, Bartelsman JF, Roos CM, Tygat GN, Jansen HM. Beneficial effect of omeprazole in a patient with severe bronchial asthma and gastro-oesophageal reflux. Eur Respir J 1988; 1: 966-968.

38. Pellegrini CA, DeMeester TR, Johnson LF, Skinner DB. Gastroesophageal reflux and pulmonary aspiration: incidence, functional abnormality, and the results of surgical therapy. Surgery 1979; 86: 110-119.

39. Foglia RP, Fonksalsrud EW, Ament ME. et al. Gastroesophageal fundoplication for the management of chronic pulmonary disease in children. Am J Surg 1980; 140: 72-79.

40. Larraine A, Corrasco E, Galleguillos F, Sepulveda R, Pope CE. Medical and surgical treatment of nonallergic asthma associated with gastro-oesophageal reflux. Chest 1991; 99: 1330-1335.

41. Lomasney TL. Hiatus hernia and the respiratory tree. Ann Thorac Surg 1977; 24: 448-450.

42. Henderson RD, Woolfe CR. Aspiration and gastrooesophageal reflux. Can J Surg 1978; 21: 352-354.

43. Perrin-Fayolle M, Bel A, Braillon G, et al. Asthme et reflux gastro-oesophagieu: result de la cure chirurgicale chez 50 malades. Poumon Coeur 1980; 36: 231237.

44. Johnson DG, Syme WC, Matlak ME, Black RE, Herbst SJ. Gastro-oesophageal reflux and respiratory disease: the place of the surgeon. Aust NZ J Surg 1984; 54: 405415.

45. Berquist WE, Rachelefsky GS, Kadden M, et al. Gastroesophageal reflux-associated recurrent pneumonia and chronic asthma in children. Pediatrics 1981, 68: 29-35. 